\title{
衝撃吸収材の臨床応用（ZDEL を用いて）
}

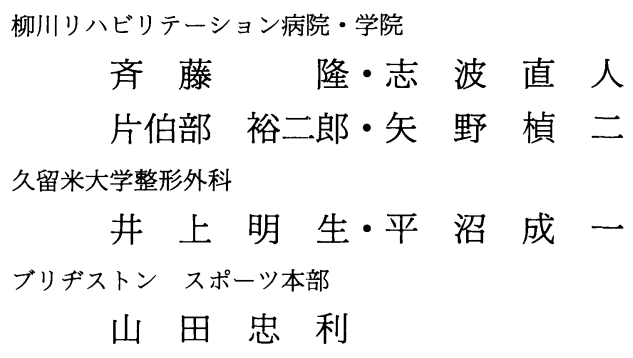

熊本総合医療福祉学院

高 島 孝 倫

\section{Clinical Applications of the Shock Absorber for the Orthosis (Using ZDEL) \\ by}

Takashi Saitou, Naoto Shiba, Yujirou Katakabe and Teiji Yano

Department of Orthopedic Surgery

Yanagawa Rehabilitation Hospital, Fukuoka, Japan

\section{Akio Inoue and Seiichi Hiranuma}

Department of Orthopedic Surgery

Kurume University School of Medicine

\section{Tadatoshi Yamada}

The Sports Department of Bridgestone Company

\section{Takanori Takashima}

Kumamoto Medical Welfare School

Here we report our study of the clinical applications of the shock absorber for the orthosis. We have already reported the result of basic reserch of the shock absorber at the 4th Japanese Medical Shoes Congress, and the result shows the shock absorber was effective in the knee and hip joint.

In this paper, we examined the clinical effect of the shock absorber on the patients who had pain in their lower extremities, and provided 51 shoe inserts for them at random.

The shock absorber was effective and reduced their pain, nearly $80 \%$ of them. We use "ZDEL" for the shock absorber. "ZEDL" has an ideal character for the orthosis such as shock absorbing ability, light weight, and easy modeling and bond.

We also reported another applications of the shock absorber for orthosis etc. such as lateral wedge for the gonarthrosis, heel of the cast, cast brace, PTB, Sarmiento brace for the tibial fracture, and the tip rubber of the crutches.

Key words : 衝撃吸収材 shock absorber, 臨床応用 clinical aplication 


\section{は じめに}

今日，スポーツシューズなどへの衝撃吸収材の使用 は常識化しており, 疾病に対する衝撃吸収材の使用の 試みもみられるようになってきている122)31. しかしな がら補装具への使用を考える場合, その材質には問題 となる点も少なくなかった. 今回, われわれは補装具 に使用可能な衝撃吸収材について検討し, 基礎実験の 結果を述べると共に, 実際の臨床への応用について検 討したので報告する.

\section{目的}

第 4 回靴医学会において報告したように基礎実験を 行い以下の結果を得た ${ }^{5)}$.

1. 衝撃吸収性能

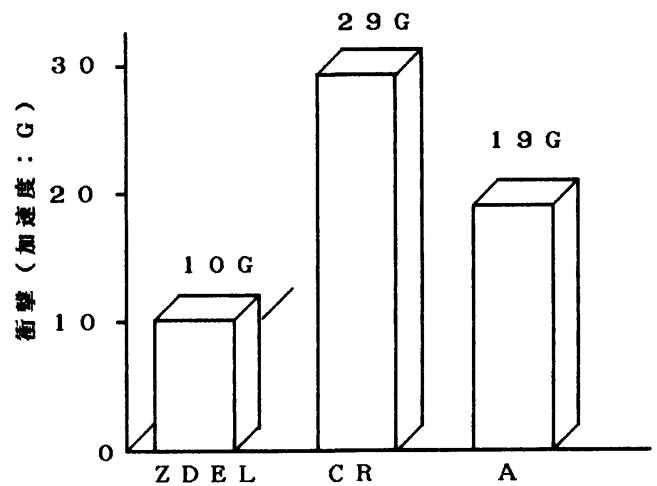

図 1 : 衝撃吸収実験結果. ZDELは装具によく使用さ れる単純性発泡ゴム (CR) や市販の衝撃吸収材 Aよりも優れた衝撃吸収性能を示した.
A. 工業的材質実験（図 1 ）

工業的材質実験は, 衝撃加速度試験方法を用いて 調查しており, 結果は厚さ $10 \mathrm{~mm}$ の ZDEL では 10 G，同じく市販衝撃吸収材 $\mathrm{A}$ では $19 \mathrm{G}$ であった。

B. 歩行実験（図 2 ）

実際の歩行中の下肢関節への衝撃吸収材の効果を 知るため, 踵部, 膝関節部, 股関節部それぞれの部位 での衝撃について検討した. 衝撃吸収材を取り付けな かった場合, 踵部にかかる衝撃は $26.6 \pm 4.0 \mathrm{G}$, 同じく 大腿骨顆部には $2.5 \pm 0.4 \mathrm{G}$ ，腸骨部には $1.7 \pm 0.2 \mathrm{G}$ の衝撃が加わる. $5 \mathrm{~mm}$ の ZDEL を貼付すると, それ ぞれ $10.1 \pm 0.7 \mathrm{G}, 1.8 \pm 0.2 \mathrm{G}, 1.5 \pm 0.04 \mathrm{G}$ ，となり， 足底に使用した衝撃吸収材は膝や股関節にも影響を与 えており, 特に股関節よりも膝関節において衝撃吸収 効果が大きかった。また，比較のため用いた市販の衝

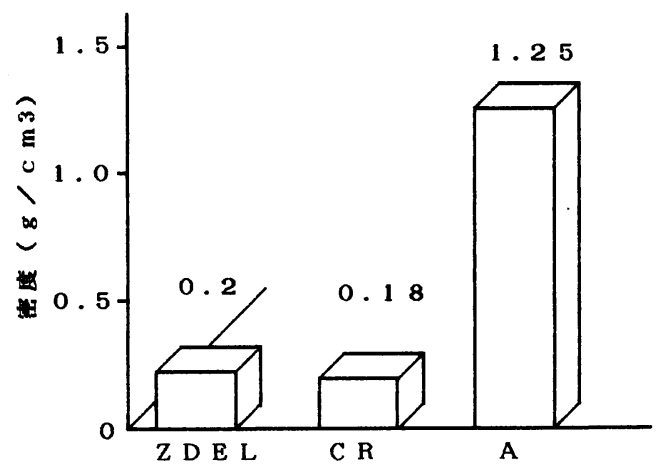

図 3 : 比重（密度）を比較すると, 単純性発泡性ゴム (CR) よりもやや重いものの, 市販の衝撃吸収 材 $\mathrm{A}$ よりも軽量であった.

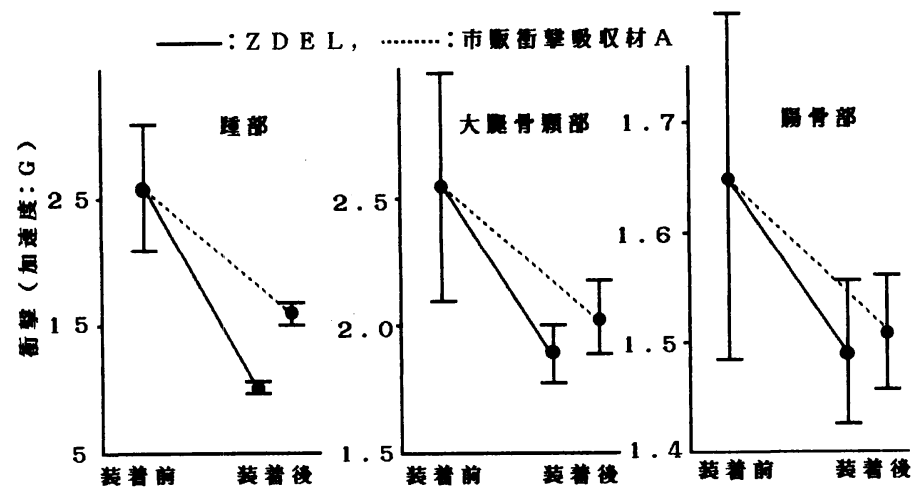

図 2 : 歩行実験結果. ZDELは踵部では $\mathrm{p}<0.001$, 大腿骨顆部で $\mathrm{p}<0.001$, 腸骨部で $\mathrm{p}<0.005$ と装着前と比較して有 意差を認めた，絶対值やp值から，股関節よりも膝関節のほうがその効果が大きいと考えられる. 
撃吸収材 $\mathrm{A}$ ではそれぞれ $16.7 \pm 1.3 \mathrm{G}, 2.1 \pm 0.2 \mathrm{G}$, $1.5 \pm 0.05 \mathrm{G}$ であった。

\section{2. 重さ (比重) (図 3 )}

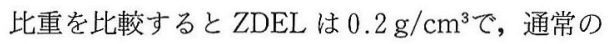
発泡ゴム (CR) の $0.18 \mathrm{~g} / \mathrm{cm}^{3}$ よりもやや重いが, 市販 衝撃吸収材 $\mathrm{A}$ の粘弾性ポリマー $1.25 \mathrm{~g} / \mathrm{cm}^{3}$ よりも軽 量であった。

\section{症例}

厚さ $5 \mathrm{~mm}$ のShoe-insert を，下肢の疼痛を主訴と する患者に at landomに処方した（図 5：a).

処方例は 28 例, 男性 9 例, 女性 19 例, 51 肢であっ た。年令は 25 才から 84 才, 平均年令 52 才 2 カ月で,

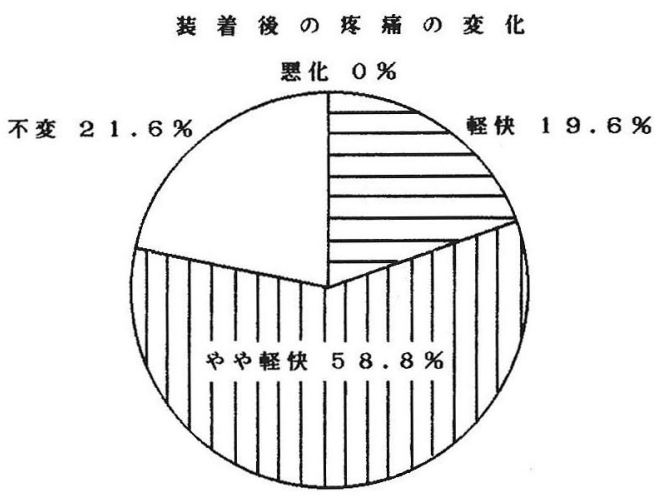

図 4 : 下肢の疼痛を主訴とする患者に処方後, 軽快, やや軽快例は各々 $19.6 \%, 58.8 \%$ であた。
その内訳は臼蓋形成不全：1 関節，変形性股関節症： 2 関節, 変形性膝関節症 : 15 関節, 半月板損傷 : 1 関 節, Morton 氏病：1肢で, その他はレントゲンなどの 諸検査で特に他賞的所見を認めない下肢に疼痛を訴え るものであった. follow 期間は, 最短 $1 \mathrm{w} よ り$ 最高 12 $\mathrm{w}$, 平均 $4 \mathrm{w}$ で, 今回は疼痛に限り評価を行なった。

\section{結果}

装着後の疼痛の変化は, 軽快 $19.6 \%$, やや軽快 58.8 \%, 不変 $21.6 \%$ 悪化したものはなかった(図 4). 障 害部位別にみると, 足部障害患者では軽快： 5 例, や や軽快：11例, 不変：2例であった。足関節障害患者 では, 軽快： 3 例, やや軽快： 3 例, 膝関節障害患者 では, 軽快： 1 例, やや軽快：10例, 不変：9例, 股 関節障害患者では, 軽快：1例, やや軽快：6例であ つた。

膝関節処方無効は 9 例であったが, 1 例は 28 才女性 の半月板損傷術後例で，他は高令者でレントゲン上明

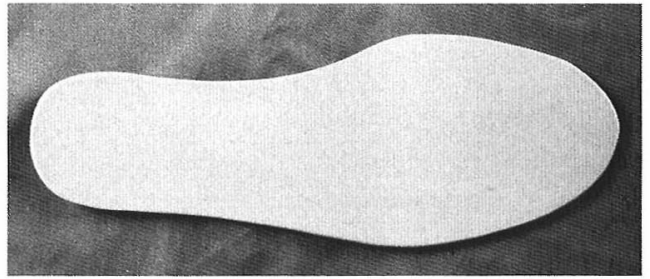

図 5 ：a. ZDELを用いた厚さ5mmのshoe insert.
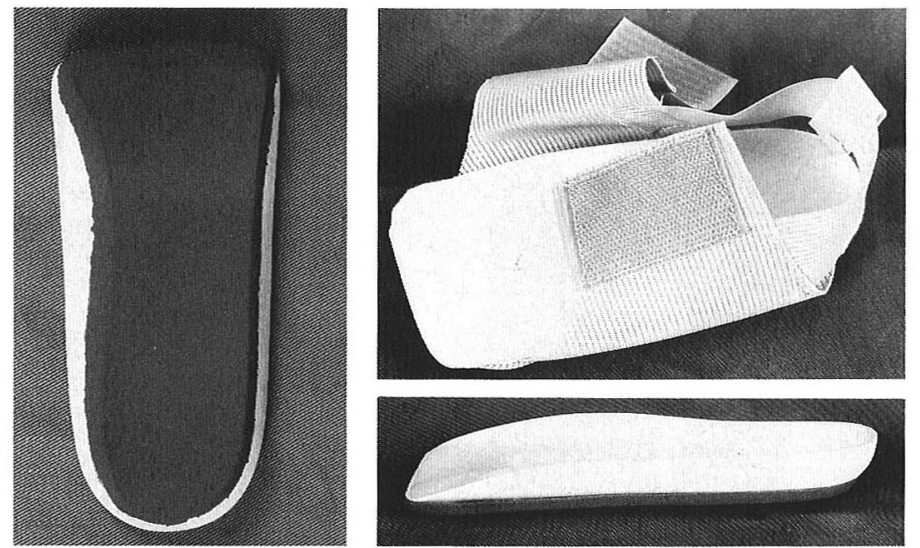

図 5 ：b. 外側楔状足底装具のalignment矯正と衝撃吸収効果を期待して外側楔状足底装具の足底部に厚さ $5 \mathrm{~mm}$ の ZDELを貼付した。 
かに変形性関節症変化があり, 内反滕を呈するもので あった。レントゲン等で基質的変化の見られなかった， 他賞的所見のない患者には全例に効果があった。

そこで，内反変形を呈する変形性膝関節症の治療用 装具として, 外側楔状足底装具の alignment 矯正効果 と衝撃吸収材の効果を期待して, 外側楔状足底装具の 足底部に厚さ $5 \mathrm{~mm}$ の衝撃吸収板を貼付したものを 作成した (図 $5: b$ ).

次に，その他整形外科の臨床に応用可能なものとし て以下のものを試作した，1） ギプスヒールへの応用 で，材質の硬いEVA スポンジの底部に衝撃吸収板を 貼付したもの（図 $5: c$ )。2）長下肢装具 cast brace の坐骨支持部分の使用例(図 $5: d$ )。3) PTB 装具の 足底に貼付し使用している例（図 $5: e$ )。 4） Sarmiento 型, 骨折治療用短下肢装具の足底部に使用した

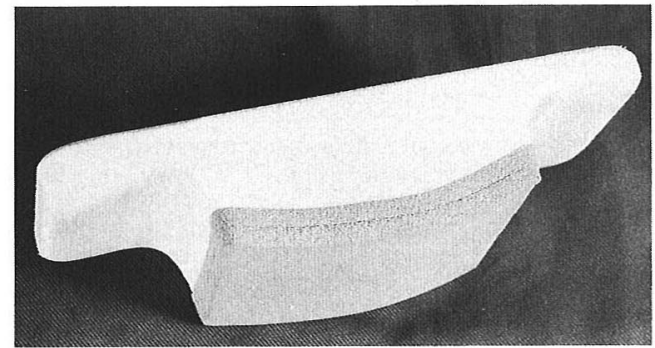

図 5 : c. ギプスヒールへの応用.

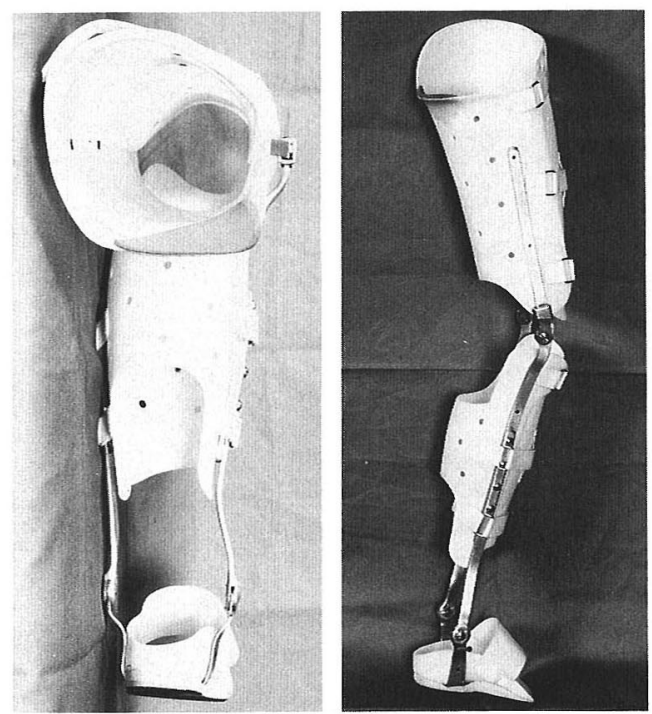

図 $5 ：$ d. 長下肢装具座骨支持部への応用.

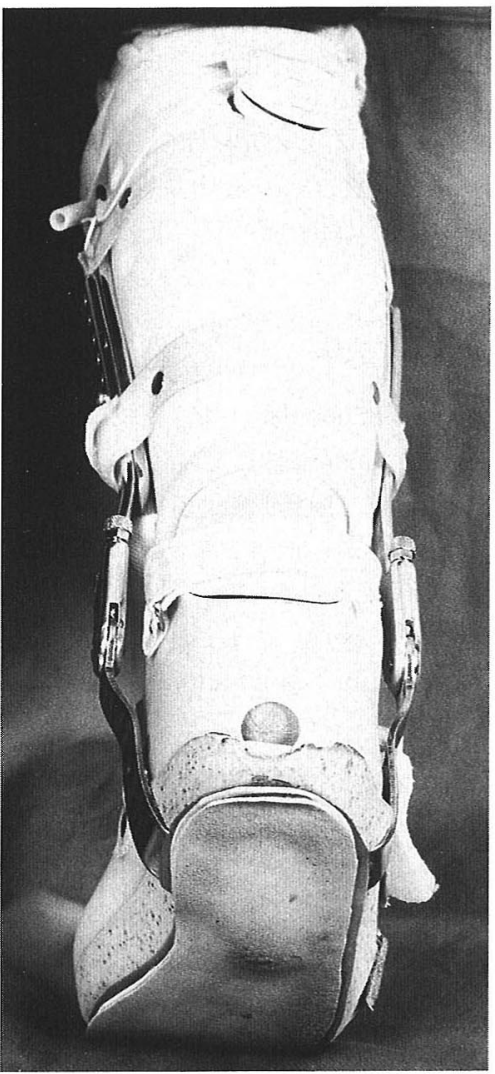

図 5 : e. 短下肢装具 (PTB) 足底部への応用.
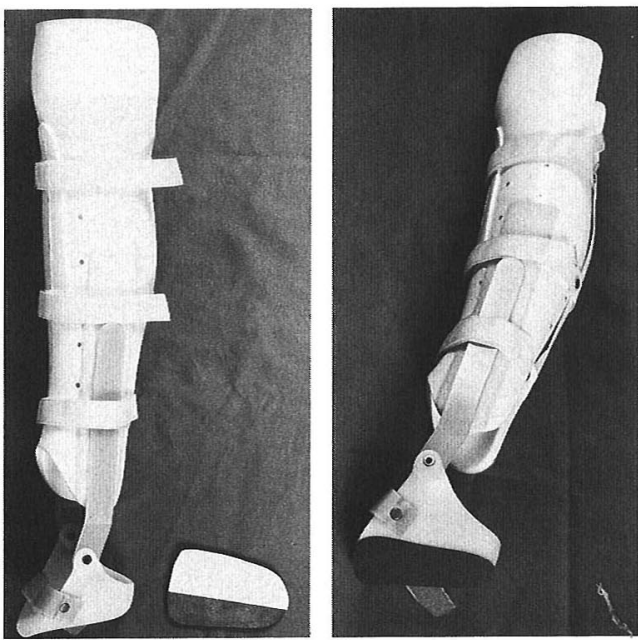

図 5 : f. Sarmiento型骨折治療用短下肢装具足底部へ の応用. 


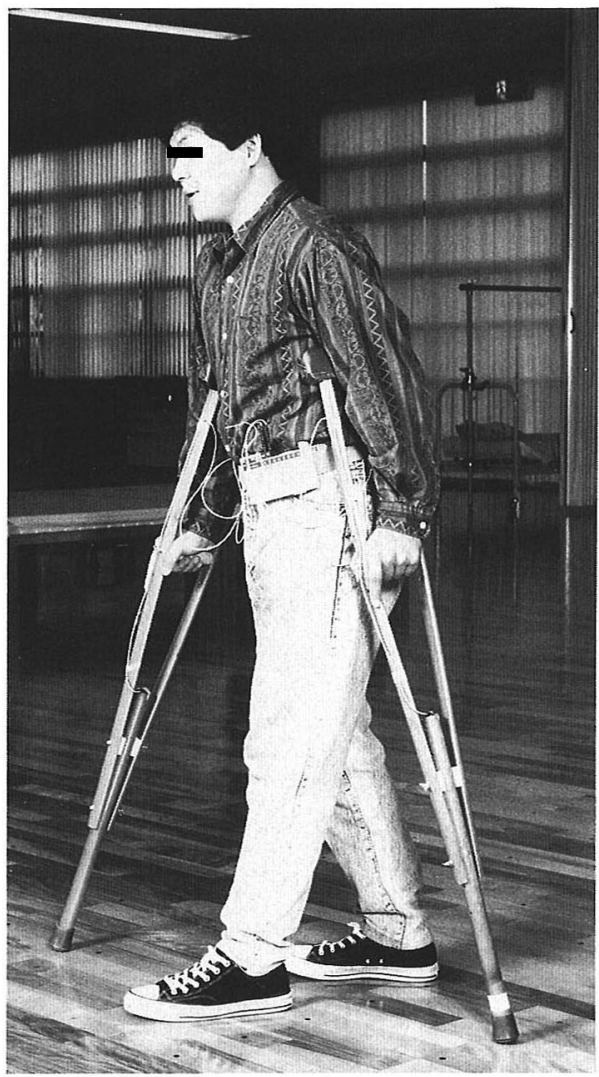

図 $5: g$. 松葉杖の杖先ゴムへの応用.

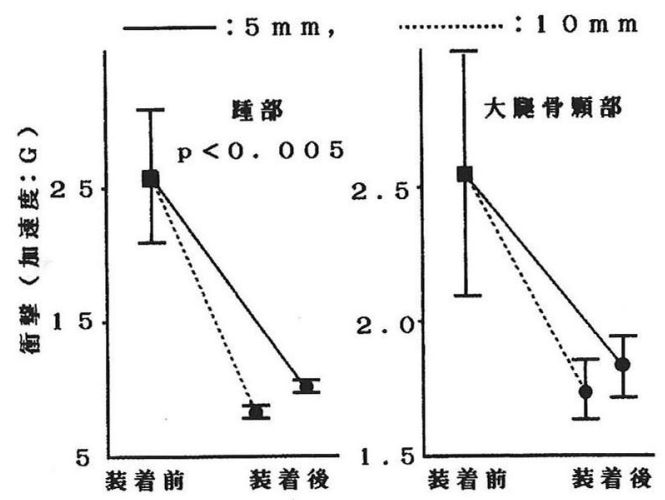

図 6：衝撃吸収材の厚さ $(5 \mathrm{~mm}, 10 \mathrm{~mm})$ による違 い. 歩行実験で, 踵部ではp $<0.005 て ゙$ 有意差を 認めるが，大腿骨顆部腸骨部では有意差を認め なかった。
もの（図 5 :f).5）松葉杖の杖先ゴムに衝撃吸収材 を用いたもの（図 $5 ： \mathrm{~g}$ ).

考察

\section{A. 衝撃吸収材の厚さ（図 6)}

歩行実験で, 衝撃吸収材の厚さによる違いを, $5 \mathrm{~mm}$ と $10 \mathrm{~mm}$ とで比較すると, 踵部では $\mathrm{p}<0.005$ で有意 差を認め, 厚いものが吸収効果が大きいことがわかる が, 膝以上の関節においては有意差はなく, 通常の歩 行パターンにおいて，豚関節にその効果を期待して衝 撃吸収材を使用する場合, $10 \mathrm{~mm}$ の厚さにする必要は なく，5 mm の厚さで充分と考えられた。

B，補装具に応用できる衝撃吸収材の条件

臨床に使用するにあたり，補装具に用いることの出 来る衝撃吸収材の条件として，

1. 優れた衝撃吸収能。

2. 軽量である。

3. 貼付切削などの加工が容易.

4. 安価である。

などが考えられる。今回われわれの用いた ZDEL は, 特殊な材質のゴムを用いた, 独立した小さな気泡 を持つスポンジ状の衝撃吸収材である。通常は $3 \mathrm{~cm}$ の厚さのシートであり，依頼して任意の厚さにスライ スし，それを用途に応じて切削，貼付して今回の補装 具等を作成した。この様な材質であるので，軽量かつ 加工が容易で補装具への使用に適していた。現材スポ ーツシューズなどに用いられている衝撃吸収材の多く は粘土状，またはゲル状の粘弾性ポリマーが多く，こ れらは比重が重く, 各病院, 施設などでの自由な加工 が困難で，補装具用には適さないものが多い。また， 補装具に使用する場合，その使用条件がスポーツシュ ーズなどとは異なることも重要で，補装具への使用を 前提として基礎実験も，それを念頭において行われる べきである(1)5).

今後は，基礎的研究及び症例を重ねると共に，多岐 にわたり臨床に応用して行きたいと考えている。

\section{ま と め}

1. 補装具への衝撃吸収材の臨床応用について報告 した.

2. 足部，足関節，滕関節，股関節にとう痛を訴え る患者に厚さ $5 \mathrm{~mm}$ の本衝撃吸収材を shoe insert と して処方した。 
3. 処方患者中, 軽快 $19.6 \%$, やや軽快 $58.8 \%$ と計 $80 \%$ に有効で，特にレントゲン等諸検査で異常を認め ない患者には全例有効であった。

4. 変形性膝関節用外側楔状装具, ギプスヒール, cast brace の坐骨支持部, PTB 装具, Sarmiento 型下 腿骨折治療用装具, 松葉杖杖先ゴム等, 実際の臨床応 用について報告した。

\section{参 考 文 献}

1）木下 博ら：ヒールパッドの緩衝効果, 臨床スポーツ
医学 $1: 289-293,1984-5$.

2）小林一敏：靴の滑りと衝撃緩衝, 整・災外 $32: 459-$ 466, 1989 .

3）大久保衛：足底支持板 (オーソテイクス) の衝撃吸収 性に関する検討,整形外科バイオメカニクス $10: 169$ $174,1988$.

4）大峰三郎：足底材の衝撃吸収効果に関する基礎的研 究 (第一報), 日本義肢装具学会誌 $46: 59-60,1989$.

5）志波直人ら：衝撃吸収材の補装具への応用に関する 基礎的研究 (特に衝撃吸収材の滕, 股関節への影響), 日本靴医学会誌 1991. in press 